\title{
Paediatric Oncology at the Crossroads: A Call for Change
}

\author{
Klaus Rose ${ }^{1}$ (iD \\ Published online: 7 October 2020 \\ (c) Springer Nature Switzerland AG 2020
}

Cancer in children is fortunately rare. It was first recognised as a challenge when infectious diseases were increasingly prevented and/or became treatable. The first successes in patient care occurred not with new drugs, but rather with well-known chemotherapeutics from the 1970s onwards [1, 2]. For the treating physicians, the approval status of those drugs was irrelevant. Physicians' focus was successful treatment; these studies were performed in the unique situation that effective drugs already existed. These studies were so successful in adult cancer patients that study participation became standard-of-care in paediatric oncology [3].

In accordance with US Federal law, the Food and Drug Administration (FDA) is not authorized to tell physicians what to prescribe, but it controls the promotional activities of pharmaceutical companies. In 1988, the term "offlabel" appeared [4], but the entire discipline of paediatric oncology emerged "off-label" decades before the term "offlabel" even existed [5, 6].

There is a fundamental difference between drug approval in general and approval/non-approval in "children" defined as younger than 17/18 years. Approval is based on science and data. But approval/non-approval in "children" is based on a misleading administrative definition [7]. There is no relevant physiological difference between 15- and 16-year-old persons. The physiological difference of 1 year is negligible in adolescents, while the difference of 1 month in babies is not [8].

Chemotherapy exposes the entire body to cell poisons in the hope of killing enough malignant cells so that the body can defeat the remaining cancer cells. Chemotherapeutics are unspecific. This helped when their use in adult cancer patients was transferred to young cancer patients, who have more reserves. Young leukaemia patients survived better than adults $[1,2]$. In relation to their bodyweight,

Klaus Rose

klaus.rose@klausrose.net

1 klausrose Consulting, Pediatric Drug Development \& More, Aeussere Baselstrasse 308, 4125 Riehen, Switzerland they tolerated higher doses. Then followed the assumption that switching targets would also work with modern anticancer drugs. However, modern anticancer drugs are not chemotherapeutics.

Paediatric oncology began in the unique situation that its key drugs existed already and "only" needed to be explored in young patients. In the most frequent childhood malignancy, acute lymphoblastic leukaemia (ALL), about $90 \%$ survived in 2000 [6, 9]. Further improvement by fine-tuning chemotherapy became limited.

New drugs were needed [10], but "paediatric" laws have achieved the contrary. First, they triggered FDA-rewarded studies, that were amplified by the European Union (EU) paediatric investigation plans (PIPs) for virtually all new drugs. Now the FDA Reauthorization Act (FDARA) authorises mandatory cancer studies with new anticancer drugs in 0 - to 11-year-old patients, copying the EU model back into the USA.

US and EU paediatric laws have divided cancer research in young patients into two streams. One specialises in "paediatric" studies with anticancer compounds that are administratively rewarded or ordered. First FDA-rewarded "paediatric" studies aimed at "paediatric" labels for chemotherapeutics that had been used for decades in combination ("cocktails"), investigating single components of these "cocktails" in administratively defined "children" aged $\leq 21$ years. Parents of minors who had relapsed after chemotherapy had been talked into such studies, emphasising that study participation was standard-of-care [3]. Around the year 2000, there was little hope for minors after relapse by use of another round of chemotherapy with just one cytotoxic. The clinical studies performed earlier by paediatric oncologists were reasonable with therapeutic intentions [1, 11]. The FDA-rewarded "paediatric" studies lacked clinical intentions. They aimed at "paediatric" labels.

Another FDA-rewarded randomised "paediatric" study investigated nasopharyngeal carcinoma (NPC) in patients aged $\leq 21$ years, comparing chemotherapy with chemotherapy plus docetaxel. The publication describes NPC as a paediatric disease [12], which is untrue [13, 14]. This study 
aimed at a 6-month patent extension ("paediatric exclusivity") [15]. Its winners were the sponsoring company, the researchers, and the FDA. Its losers were the patients and their parents.

PIP-triggered studies include "paediatric" studies with ribociclib in patients aged $\leq 21$ years with various cancer types [16]; two "paediatric" melanoma studies that were terminated because recruitment waned as the PIP-demanded monotherapy was below standard-of-care $[17,18]$; a "paediatric" temsirolimus study in patients aged $\leq 21$ years with various cancer types [19], two "paediatric" sonidegib studies in patients aged $\leq 18$ years with various cancer types [20], and a "paediatric" study adding bevacizumab to chemotherapy in patients aged 6 months to $<18$ years [21]. Why should cancer types that occur before and after the 18th or 21 st birthday react differently to the same compound before and after the 18th/21st birthday? These studies had no positive outcome. Their entire rationale was flawed. They did not help. The melanoma studies even caused harm with treatment below standard-of-care $[17,18]$. Nobody has apologised [18].

PIP-triggered studies are financed by pharmaceutical companies as an "entrance fee" into the EU market. A coalition of FDA/EMA, clinical researchers, pharmaceutical companies and commercial clinical research has been formed, allowing and justifying "paediatric" careers in these institutions.

Many cancer types frequently found in adults can occasionally affect patients before their 18th birthday. Conventional melanoma in a 15-year-old patient is not "paediatric" because s/he is legally still a child $[18,22]$. Thirteen EU PIPs demand "paediatric" studies in various cancer types including melanoma [18]. PIP-triggered studies recruit worldwide. Leukaemia in a 25-year-old is fundamentally not different from leukaemia in a 15-year-old. Also PIPdemanded "paediatric" leukaemia studies are questionable $[6,7,18]$.

Before FDARA, the FDA could not mandate studies in rare diseases. All paediatric cancers are rare [1]. FDA/EMAtriggered "paediatric" cancer studies are based on a flawed rationale, making empty promises towards patients, parents, and politicians. This is covered by the law. It is an extraordinary and historically unique situation that the law justifies studies that range between useless, exaggerated, and harmful. All these studies recruit worldwide [23-25].

US FDARA translates the fear and despair of parents and the hidden conflicts of today's main players of "paediatric" oncology into a system of empty promises. "Something" is done, but it is useless. This waste of funds and energy jeopardises public trust in science, research, education and authorities.

Cancer treatment changed with targeted therapies: since imatinib, chronic myelogenous leukaemia is no longer lethal. CAR-T cell therapy against relapsed/refractory ALL can help the $10 \%$ who until recently were doomed.

Emily Whitehead contracted ALL when she was aged 5 years. She went through routine chemotherapy and relapsed. Her parents enrolled her in a reasonable study, blood was taken, her T-cells were re-programmed to attack ALL cells, and were re-infused. A cytokine storm with high fever was successfully treated with tocilizumab. Emily recovered. Today, she is healthy and cancer free [26-28]. She was lucky, being referred to a reasonable study. Had she entered one of the many PIP-demanded studies, she would likely be dead. Reasonable studies that are based on a truly scientific rationale and test advanced treatment compete for patients with EMA/FDA-triggered questionable studies [6, 7, 18, 23-25].

The term "paediatric" oncology is not based on science. It is administrative. When a 15-year-old with conventional melanoma is admitted to a hospital, administrative rules decide into which ward s/he will be placed. But his/her cancer is neither "paediatric" in a paediatric ward nor adult in an adult ward [18, 22]. Treatment should be the same.

Paediatric legislation has changed the position of paediatric oncology from a niche towards a voice to be heard. This was a political transformation. This was perceived as a step forward, but became an obstacle against further progress.

The FDA has partially stepped back from "paediatric" cancer studies. It now recommends that adolescents be included in adult cancer studies [29], thus admitting that all "paediatric" cancer studies in 12- to 21-year-old patients since 1997 were useless and worse. The FDA has shown some flexibility without abandoning the concept of children as "therapeutic orphans" and "paediatric drug development" [30]. The EMA has progressed further into regulatory dogmatism, now considering liver and intrahepatic bile duct carcinoma, and kidney and renal pelvis carcinoma as "paediatric" diseases and demanding PIPs for these malignancies that occasionally occur in patients before their 18th birthday [31].

"Paediatric" cancer is not defined by transparent scientific terms, but as what is seen by paediatric oncologists, which is circular. Leading journals report on "paediatric" cancer; the examined tissue is from patients $\leq 25$ years of age [32]; $98.5 \%$ of tissue from patients $\leq 20$ years of age (no upper age limit for the rest) [33]; "paediatric" cancer defined as in patients $\leq 14$ years of age [34]. The genomic alterations described in these papers would not justify business investments, but they are used to justify FDA/EMA-mandated studies [32-35].

Clinical oncology, regulatory authorities, and industry have so far not addressed the difference between legal and administrative classification of young persons as "children". Malignant cells are malignant. Period. Types of malignancy 
differ across age groups. Their clinical course differs in different ages, but they are not entirely different diseases.

It is likely that the FDA/EMA-triggered "paediatric" studies in cancer and other diseases are the largest patient abuse in medical research history [9]. Clinical studies with therapeutic intentions compete for patients with questionable studies. Science and medicine must tackle this challenge, or public trust will be jeopardised.

\section{Declarations}

Funding No funding was received for this manuscript.

Conflict of interest Klaus Rose has worked for pharmaceutical companies for 20 years and for 10 years has been advising on FDA/EMArequested/demanded paediatric studies.

Ethics approval Not applicable.

Consent to participate Not applicable.

Consent for publication Not applicable.

Availability of data and material Not applicable.

Code availability Not applicable.

Author contributions This manuscript was written, revised and approved for publication by Klaus Rose.

\section{References}

1. Adamson PC. Improving the outcome for children with cancer: development of targeted new agents. CA Cancer J Clin. 2015;65(3):212-20.

2. DeVita VT Jr, Chu E. A history of cancer chemotherapy. Cancer Res. 2008;68(21):8643-53. https://cancerres.aacrjournals.org/ content/68/21/8643.full-text.pdf. Accessed 15 Sept 2020.

3. FDA Pemetrexed pediatric written request 2001. https://www.fda. gov/media/80043/download. Accessed 15 Sept 2020.

4. Plate V. The Impact of Off-Label, Compassionate and Unlicensed Use on Health Care Laws in preselected Countries. https://hss.ulb. uni-bonn.de/2009/1936/1936.pdf. Accessed 15 Sept 2020.

5. Rose K. The Challenges of pediatric drug development. Curr Ther Res Clin Exp. 2020;2019(90):128-34. https://doi.org/10.1016/j. curtheres.2019.01.007.Accessed15September.

6. Rose K, Neubauer D, Grant-Kels JM. Rational use of medicine in children-the conflict of interests story. A review. Rambam Maimonides Med J. 2019; 10(3): e0018. https//doi.org/https:// doi.org/10.5041/RMMJ.10371. https://www.rmmj.org.il/useri mages/928/2/PublishFiles/953Article.pdf. Accessed 15 Sept 2020 (Review).

7. Rose K, Grant-Kels JM. The meanings of "Pediatric Drug Development". A review. Ther Innov Regul Sci. 2018;53(6):767-74. https://doi.org/10.1177/2168479018812060.

8. Kearns GL, Abdel-Rahman SM, Alander SW, Blowey DL, Leeder JS, Kauffman RE. Developmental pharmacology—drug disposition, action, and therapy in infants and children. $\mathrm{N}$ Engl J Med. 2003;349(12):1157-67.
9. Rose K. Considering the patient in pediatric drug development. How good intentions turned into harm. London: Elsevier; 2021 (In press).

10. Boklan J. Little patients, losing patients: pediatric cancer drug development. Mol Cancer Ther. 2006;5(8):1905-8. https://mct. aacrjournals.org/content/5/8/1905.full-text.pdf. Accessed 15 Sept 2020.

11. Norris RE, Adamson PC. Challenges and opportunities in childhood cancer drug development. Nat Rev Cancer. 2012;12(11):776-82.

12. Casanova M, Enis Özyar E, Patte C, Orbach D, Ferrari A, Veyrat-Follet $\mathrm{C}$, et al. International randomized phase 2 study on the addition of docetaxel to the combination of cisplatin and 5-fluorouracil in the induction treatment for nasopharyngeal carcinoma in children and adolescents. Cancer Chemother Pharmacol. 2016;77(2):289-98.

13. Kamran SC, Riaz N, Lee N. Nasopharyngeal carcinoma. Surg Oncol Clin N Am. 2015;24:547-61.

14. Brennan B. Nasopharyngeal carcinoma. Orphanet J Rare Dis. 2006;1:23.

15. FDA 2001. The Pediatric Exclusivity Provision. Status Report to Congress. 2001. https://www.fda.gov/downloads/Drugs/Devel opmentApprovalProcess/DevelopmentResources/UCM049915. pdf. Accessed 15 Sept 2020.

16. Geoerger B, Bourdeaut F, DuBois SG, et al. A phase I study of the CDK4/6 inhibitor ribociclib (LEE011) in pediatric patients with malignant rhabdoid tumors, neuroblastoma, and other solid tumors. Clin Cancer Res. 2017;23(10):2433-41.

17. Geoerger B, Bergeron C, Gore L, et al. Phase II study of ipilimumab in adolescents with unresectable stage III or IV malignant melanoma. Eur J Cancer. 2017;86:358-63.

18. Rose K, Grant-Kels JM. Pediatric melanoma-the whole (Conflicts of Interest) Story. Int J Womens Dermatol 2018;5(2):110 115. https://doi.org/https://doi.org/10.1016/j.ijwd.2018.10.020. https://www.ncbi.nlm.nih.gov/pmc/articles/PMC6451736/pdf/ main.pdf. Accessed 15 Sept 2020.

19. Geoerger B, Kieran MW, Grupp S, et al. Phase II trial of temsirolimus in children with high-grade glioma, neuroblastoma and rhabdomyosarcoma. Eur J Cancer. 2012;48(2):253-62. https ://www.ncbi.nlm.nih.gov/pmc/articles/PMC3539305/pdf/nihms 430534.pdf. Accessed 15 Sept 2020.

20. Kieran MW, Chisholm J, Casanova M, et al. Phase I study of oral sonidegib (LDE225) in pediatric brain and solid tumors and a phase II study in children and adults with relapsed medulloblastoma. Neuro Oncol. 2017;19(11):1542-1552. https://www. ncbi.nlm.nih.gov/pmc/articles/PMC5737275/pdf/nox 109.pdf. Accessed 15 Sept 2020.

21. Chisholm JC, Merks JHM, Casanova M, et al. Open-label, multicentre, randomised, phase II study of the EpSSG and the ITCC evaluating the addition of bevacizumab to chemotherapy in childhood and adolescent patients with metastatic soft tissue sarcoma (the BERNIE study). Eur J Cancer. 2017;83:177-84.

22. Pappo AS. Pediatric melanoma: the whole (genome) story. Am Soc Clin Oncol Educ Book. 2014;34:e432-5.

23. Rose K, Grant-Kels JM. Questionable international pediatric studies in the United States and Russia triggered by regulatory authorities. Asian J Res Med Pharm Sci 2018;3(3).https://www. journalrepository.org/media/journals/AJRIMPS_63/2018/Apr/ Rose332018AJRIMPS40776.pdf. Accessed 15 Sept 2020.

24. Rose K, Neubauer D, Grant-Kels JM. Rational use of medicine in children - the conflict of interests story. A review. Rambam Maimonides Med J. 2019; 10(3): e0018. https://doi.org/https:// doi.org/10.5041/RMMJ.10371. https://www.rmmj.org.il/useri mages/928/2/PublishFiles/953Article.pdf. Accessed 15 Sept 2020 (Review). 
25. Rose K, Neubauer D, Grant-Kels JM. Questionable industrysponsored studies in children and adolescents in Slovenia. Curr Ther Res Clin Exp. 2019. https://doi.org/10.1016/j.curth eres.2019.01.002.

26. Emily Whitehead: A Young Girl Beats Cancer with Immunotherapy. https://www.cancerresearch.org/immunotherapy/stories/patie nts/emily-whitehead. Accessed 15 Sept 2020.

27. Maude SL, Laetsch TW, Buechner J, et al. Tisagenlecleucel in children and young adults with B-cell lymphoblastic leukemia. N Engl J Med. 2018:378:439-48.

28. FDA. 2017. Tisagenlecleucel label https://www.fda.gov/files/vacci nes $\% 2$ C\%2520blood\%2520\%26\%2520biologics/published/Packa ge-Insert---KYMRIAH.pdf. Accessed 15 Sept 2020.

29. FDA. 2019. Considerations for the inclusion of adolescent patients in adult oncology clinical trials. Guidance for Industry. https:// www.fda.gov/media/113499/download. Accessed 15 Sept 2020.

30. Ward RM, Benjamin DK Jr, Davis JM, et al. The need for pediatric drug development. J Pediatr. 2018;192:13-211.
31. EMA. 2015. EMA/PDCO Summary Report on the review of the list of granted Class Waivers. https://www.ema.europa.eu/en/ documents/other/ema/pdco-summary-report-review-list-grant ed-class-waivers_en.pdf. Accessed 15 Sept 2020.

32. Gröbner SN, Worst BC, Weischenfeldt J, et al. The landscape of genomic alterations across childhood cancers. Nature. 2018;555(7696):321-7.

33. Ma X, Liu Y, Liu Y, Alexandrov LB, Edmonson MN, et al. Pancancer genome and transcriptome analyses of 1699 paediatric leukaemias and solid tumours. Nature. 2018;555(7696):371-6.

34. Sweet-Cordero EA, Biegel JA. The genomic landscape of pediatric cancers: implications for diagnosis and treatment. Science. 2019;363(6432):1170-5.

35. Pearson AD, Herold R, Rousseau R, et al. Implementation of mechanism of action biology-driven early drug development for children with cancer. Eur J Cancer. 2016;62:124-31. 